\title{
IMPLEMENTASI PROGRAM PENGARUSUTAMAAN GENDER BIRO PEMBERDAYAAN PEREMPUAN DAN KESEJAHTERAAN RAKYAT DI PROVINSI GORONTALO
}

\author{
Maryam D. Poma ${ }^{1}$; Nolfi S. Tueno ${ }^{2}$ \\ STIA Bina Taruna Gorontalo \\ maryampoma87@gmail.com ${ }^{1}$; nolfitueno22@g.mail.com ${ }^{2}$
}

\begin{abstract}
ABSTRAK
Tujuan penelitian ini adalah untuk mengetahui sejauh mana Implementasi Program Pengarusutamaan Gender Biro Pemberdayaan Perempuan dan Kesejahteraan Rakyat di Provinsi Gorontalo. Metode penelitian yang digunakan dalam penelitian ini adalah deskriptif dengan pendekatan kualitatif. Adapun teknik pengumpulan data yang digunakan dalam penelitian ini adalah teknik observasi, wawancara dan dokumentasi, dengan teknik analisis data yang digunakan adalah teknik analisis kualitatif. Hasil penelitian bahwa keberhasilan pelaksanaan program pengarusutamaan gender memperkuat kehidupan sosial politik dan ekonomi suatu bangsa, dimana strategi yang dilakukan secara rasional dan sistematis untuk mencapai dan mewujudkan kesetaraan dan keadilan gender dalam sejumlah aspek kehidupan manusia melalui kebijakan dan program yang memperhatikan pengalaman, aspirasi, kebutuhan dan permasalahan perempuan dan laki-laki ke dalam perencanaan, pelaksanaan, pengawasan dan evaluasi dari seluruh kebijakan dan program diberbagai bidang kehidupan dan pembangunan. Adapun fokus penelitian adalah perencanaan, pelaksanaan,pengawasan dan evaluasi. Strategi dalam teknik analisis data deskriptif kualitatif pada dasarnya memiliki sifat yang tidak terlalu mengutamakan makna, sebaliknya penekanannya lebih banyak menganalisi permukaan data, hanya memperhatikan proses-proses kejadian suatu fenomena.
\end{abstract}

Kata Kunci: Implementasi; Program; Pengarusutamaan; Gender

\begin{abstract}
The purpose of this study was to determine the extent of the implementation of the Gender Mainstreaming Program for the Bureau of Women's Empowerment and People's Welfare in Gorontalo Province. The research method used in this research is descriptive with a qualitative approach. The data collection techniques used in this study were observation, interviews and documentation techniques, with data analysis techniques used were qualitative analysis techniques. The results of the study show that the successful implementation of gender mainstreaming programs strengthens the socio-political and economic life of a nation, where strategies are carried out rationally and systematically to achieve and realize gender equality and justice in a number of aspects of human life through policies and programs that take into account experiences, aspirations, needs and problems of women and men into the planning, implementation, monitoring and evaluation of all policies and programs in various fields of life and development. The research focus is planning, implementation, monitoring and evaluation. The strategy in qualitative descriptive data analysis techniques basically has a nature that does not prioritize meaning, on the contrary, the emphasis is more on analyzing the data surface, only paying attention to the processes of occurrence of a phenomenon.
\end{abstract}

Keywords: Implementation; Program; Mainstreaming; Gender 


\section{PENDAHULUAN}

Keberhasilan pembangunan dalam proses historis kehidupan dalam semua tingkatan akan sangat tergantung pada peran serta laki-laki dan perempuan secara bersamaan sebagai pelaku dan pemanfaat. Ketidakseimbangan serta peminggiran terhadap peran serta dari salah satu elemen tersebut bisa berakibat pada ketimpangan dan ketidakadilan. Oleh karena itu, semua program pemberdayaan harus memperhatikan dan diorientasikan pada pencapaian dan optimalisasi peran yang setara antara laki-laki dan perempuan.

Persoalan kesenjangan gender yang terjadi di kelembagaan maupun di masyarakat Gorontalo sebagai penerima manfaat atau sasaran program, salah satu penyebabnya adalah lemahnya pemahaman tentang konsep gender. Disertai dengan adanya pemahaman yang keliru tentang konsep gender sehingga mempengaruhi pola pikir dan perilaku gender. Oleh karena itu, menjadi sangat penting mengetahui konsep pengarusutamaan gender yang dikonsepkan melalui kebijakan.

Meskipun demikian pemerintah bersama masyarakat dan swasta ditugaskan membentuk mekanisme untuk mempercepat perwujudan keadilan dan kesetaraan gender, dalam berbagai aspek dan kehidupan publik di semua tingkatan. Strategi pembangunan yang digunakan dalam mewujudkan kesetaraan dan keadilan gender dengan melakukan pengarusutamaan gender (PUG) melalui pengintegrasian pengalaman, aspirasi, kebutuhan dan permasalahan perempuan dan laki-laki ke dalam perencanaan, pelaksanaan, pemantauan dan evaluasi dari seluruh kebijakan.

Berdasarkan Instruksi Presiden (INPRES, n.d.) No 9 Tahun 2000 tentang Pengarusutamaan gender dalam pembangunan nasional Presiden Republik Indonesia serta di tingkat pemerintah Provinsi Gorontalo, komitmen ini telah diwujudkan melalui Kebijakan dan Strategi Pembangunan Pemberdayaan Perempuan, Kesejahteraan dan Perlindungan di Provinsi Gorontalo sebagai tindak lanjut dari Keputusan Gubernur Gorontalo No.189/04/VII/2008 tentang Pembentukan Kelompok Kerja Pengarustamaan Gender (Pokja PUG) Provinsi Gorontalo.

Kebijakan pembangunan pemberdayaan perempuan di Provinsi Gorontalo ini pada hakekatnya diarahkan pada peningkatan: 1. Kedudukan, Peran, Kemampuan, Kemandirian serta ketahanan mental spiritual dan menjadi mitra yang selaras serasi dan seimbang; 2. Peningkatan kualitas sumber daya manusia; 3. Program yang sinergi baik dengan pusat, daerah maupun dengan lembaga-lembaga di masyarakat.

Dalam Peraturan Menteri Dalam Negeri Nomor 15 Tahun 2008 tentang Pedoman Umum Pelaksanaan Pengarustamaan Gender di Daerah, Pasal 10 dijelaskan mengenai tugas utama Pokja PUG di tingkat Provinsi. Dalam Rakornas Pemberdayaan Perempuan dan Perlindungan Anak yang dilaksanakan pada tahun 2010 yang lalu telah disepakati beberapa program yang akan menjadi panduan bagi pemerintah, pemerintah provinsi 
dan pemerintah kabupaten/kota dalam upaya peningkatan kapasitas perempuan dalam strategi gender serta perlindungan anak. Poin-poin program tersebut adalah: a. Aspek Kelembagaan yang merupakan wadah untuk melakukan koordinasi, pembinaan, pengawasan pembangunan pemberdayaan perempuan dan perlindungan anak: b. Aspek Pemberdayaan yang bertujuan meningkatkan kemampuan kinerja Pemerintah Daerah melalui peningkatan kualitas sumberdaya manusia dalam pelaksanaan pembangunan pemberdayaan perempuan dan perlindungan anak dengan mengefektifkan peran tokoh agama, tokoh masyarakat, tokoh adat untuk menciptakan lingkungan sosial yang kondusif bagi pembangunan pemberdayaan perempuan dan perlindungan anak sebagai peran pusat studi terutama PSW/PSG maupun lembaga masyarakat terkait dalam meningkatkan kapasitas fokal poin dan pokja PUG di kabupaten/kota serta kemampuan perempuan untuk berperan aktif dalam mekanisme perencanaan tingkat desa dan membangun mekanisme perencanaan khusus perempuan sejalan dengan mekanisme program yang menjadi mainstreamnya.

Untuk daerah Provinsi Gorontalo khususnya, tercapainya program-program yang berkaitan erat dengan strategi peningkatan pengarusutamaan gender kemungkinan masih sama dengan kondisi di daerah lain pada umumnya. Dimana, dapat dilihat dari masih rendahnya angka partisipasi perempuan di semua bidang baik politik, pemerintahan, masih kurangnya perhatian dan upaya dalam meningkatkan kualitas hidup perempuan terutama pada masyarakat dengan tingkat ekonomi yang rendah. Dalam kajian adat istiadat yang masih dijunjung tinggi oleh masayarakat Gorontalo dalam setiap pelaksanaan kegiatan, keterlibatan perempuan dalam adat memang sangat kecil. Dimana, kaum perempuan hanyalah sebagai pelengkap sementara semua peran dalam prosesi-prosesi adat didominasi oleh laki-laki.

Dalam kajian masyarakat lokal Gorontalo dengan penguatan kapasitas melalui motto "adat bersendikan sara, sara bersendikan kitabullah" telah menegaskan bahwa peran perempuan dalam lini sosial kemasyarakatan sangat kecil, dan hal inipun telah menjalar pada lini lainnya yaitu politik. Pada intinya, Provinsi Gorontalo masih perlu peningkatan kualitas hidup manusianya, termasuk partisipasi perempuan dalam semua sektor pembangunan. Dimana belum adanya upaya pemerintah Provinsi Gorontalo dalam mensosialisasikan pentingnya gender, serta belum adanya koordinasi dan kerjasama yang sinergi antara pemerintah provinsi dan kabupaten/kota dalam menjalankan program pengarusutaman gender. Urgensi permasalahan yang perlu diungkapkan dalam penelitian ini adalah: Bagaimana Implementasi Program Pengarusutamaan Gender Di Provinsi Gorontalo.

Dalam kaitan itu, menurut (Winarno, 2014), implementasinya dipandang dalam pengertian yang luas merupakan alat administrasi hukum dimana berbagai aktor, organisasi, prosedur dan teknik yang bekerja bersama-sama untuk menjalankan 
kebijakan guna meraih dampak atau tujuan yang diinginkan. Implementasi pada sisi yang lain merupakan fenomena yang kompleks yang dapat dipahami sebagai proses, keluaran (output) maupun sebagai hasil". Membatasi implementasi kebijakan sebagai tindakan-tindakan yang dilakukan oleh individu-individu (atau kelompok-kelompok) pemerintah maupun swasta yang diarahkan untuk mencapai tujuan-tujuan yang telah ditetapkan dalam keputusan-keputusan kebijakan sebelumnya.

Tindakan-tindakan ini mencakup usaha-usaha untuk mengubah keputusankeputusan menjadi tindakan-tindakan operasional dalam kurun waktu tertentu maupun dalam rangka melanjutkan usaha-usaha untuk mencapai perubahan-perubahan besar dan kecil yang ditetapkan oleh keputusan-keputusan kebijakan. Sedangkan menurut (Tahir, 2014), memahami implementasi sebagai berikut: "Implementation process involve many important actors holding diffuse and competing goals and expectations who work within a contexts of an increasingly large and complex mix of government programs the require participation from numerous layers and units of governemnt and who are affected by powerful factors beyond their control".

Pengertian tersebut menunjukkan bahwa kompleksitas implementasi bukan saja ditunjukkan oleh banyaknya aktor atau unit organisasi yang terlibat, tetapi juga dikarenakan proses implementasi dipengaruhi oleh berbagai variabel yang kompleks, baik variabel yang individual maupun variabel organisasional, dan masing-masing variabel pengaruh tersebut juga saling berinteraksi satu sama lain. (Tangkilisan, 2013), mengutip pendapat lain bahwa "Keseluruhan proses penetapan kebijakan baru bisa mulai apabila tujuan dan sasaran yang semula bersifat umum telah terperinci, program telah dirancang dan juga sejumlah dana telah dialokasikan untuk mewujudkan tujuan dan sasaran tersebut. Program adalah kata, ekspresi, pernyataan atau kombinasi yang disusun dan dirangkai menjadi satu kestauan prosedur yang berupa urutan langkah untuk menyelesaikan masalah yang diimplementasikan dengan menggunakan bahasa pemrograman sehinga dapat dieksekusi.

Menurut (Binanto, 2012) kata program dan pemrograman dapat diartikan sebagai berikut: a. Mendeskripsikan instruksi-instruksi tersendiri yang biasanya disebut source code yang dibuat oleh programmer; $b$. Mendeskripsikansuatu keseluruhan bagian dari software yang executable; c. Program merupakan himpunan atau kumpulan instruksi tertulis yang dibuat oleh programmer atau suatu bagian executable dari suatu software. Pemrograman berarti membuat program computer; d. Pemrograman merupakan suatu kumpulan urutan perintah ke komputer untuk mengerjakan sesuatu. Perintah-perintah ini membutuhkan suatu bahasa tersendiri yang dapat dimengerti oleh komputer.

Sedangkan menurut (Yulikospartono, 2013) mengemukakan bahwa, "program merupakan sederetan instruksi atau statement dalam bahasa yang dimengerti oleh 
komputer yang bersangkutan", serta kata pemrograman menurut (Sugiyono, 2014) adalah "suatu rangkaian instruksi-instruksi dalam bahasa komputer yang disusun secara logis dan sistematis". Menurut (Hartono, 2010) program diterapkan, maka program harus bebas terlebih dahulu dari kesalahan-kesalahan. Oleh sebab itu program harus diuji untuk menemukan kesalahan-kesalahan yang mungkin dapat terjadi. Kesalahan dari program yang mungkin terjadi dapat diklasifikasikan dalam dua bentuk kesalahan, antara lain: a. Kesalahan Bahasa (Language Errors), Kesalahan di dalam penulisan source program yang tidak sesuai dengan yang telah disyaratkan; b. Kesalahan dalam Proses (Run Time Errors)

Aktifitas program sangat memerlukan pertimbangan yang sistematis, terencana, analisis sebab akibat, penyusunan kriteria, serta deskripsi program yang jelas. Pertimbangan-pertimbangan di atas diperlukan, terutama untuk mengetahui kekuatan dan kelemahan program itu. Dan hal ini pula yang menjadi pedoman mengapa diperlukan evaluasi.

Konsep-konsep Utama Terkait Gender Gender berasal dari bahasa Inggris yang berarti Jenis Kelamin. Dalam bidang Ensiklopedia Feminisme (Maggie Hum, 2010), gender diartikan sebagai kelompok atribut dan perilaku yang dibentuk secara kultural yang ada pada laki-laki dan perempuan. Dapat pula diartikan suatu pemahaman sosial budaya tentang apa dan bagaimana lelaki dan perempuan seharusnya berperilaku. Pengertian lain yang dikemukakan yaitu bahwa pembentukan gender ditentukan oleh sejumlah faktor yang ikut membentuk, kemudian disosialisasikan, diperkuat, bahkan dikonstruksikan melalui sosial atau kultural, dilanggengkan oleh interpretasi agama dan mitos-mitos seolah-olah telah menjadi kodrat antara laki-laki dan perempuan. Perbedaan laki-laki dan perempuan sesungguhnya tidak menjadi masalah. Perbedaan tersebut menjadi bermasalah ketika menghasilkan ketidakadilan terhadap jenis kelamin tertentu.

Gender merupakan pemahaman atau pandangan masyarakat tentang perbedaan peran, fungsi dan tanggung jawab antara perempuan dan laki-laki yang merupakan hasil konstruksi sosial budaya dan dapat berubah sesuai dengan perkembangan zaman dan dukungan masyarakat itu sendiri (buku saku KPP 2000).

Konsep gender mengacu pada peran dan tanggung jawab sebagai perempuan dan sebagai laki-laki yang diciptakan dan diinternalisas dalam keluarga, dalam masyarakat, dalam budaya masyarakat dimana kita hisup termasuk harapan-harapan, sikap, sifat, perilaku bagaimana menjadi seorang laki-laki dan bagaimana menjadi seorang perempuan (cultural learned and assigned behaviour) dengan 3 peran utama yaitu: a. Peran Produktif yang berkaitan dengan pemeliharaan sumber daya manusia atau kelangsungan hidup manusia termasuk mengasuh anak dan pekerjaan rumah tangga lainnya; b. Peran Reproduktif yang berkaitan dengan usaha menghasilkan barangbarang dan pelayanan, baik untuk dikonsumsi maupun untuk diperdagangkan guna 
untuk mendapatkan penghasilan; c. Peran Sosial Budaya yang berkaitan dengan semua kegiatan didalam masyarakat, seperti partisipasi dalam kelompok yang teroganisir.

Istilah pengarusutamaan gender mengadopsi istilah gender mainstreaming yang didengungkan oleh Beijing Platform for Action (BPFA) pada konfrensi PPB untuk perempuan IV tahun 1995. Namun definisi yang sering digunakan oleh Negara-negara dan lembaga pembangunan adalah istilah versi United Economic and Social Council (1997) yaitu, mengarustamakan perspektif gender adalah proses memeriksa pengaruh terhadap perempuan dan laki-laki setelah dilaksanakannya sebuah rencana, termasuk dalam proses legislasi dan program-programnya dalam berbagai bidang dan di semua tingkat. Definisi PUG yang saat ini banyak diadopsi oleh negara-negara dan lembagalembaga pembangunan adalah versi United Nations Economic and Social Council yaitu: "mengarusutamakan perspektif gender adalah proses memeriksa pengaruh terhadap perempuan dan laki-laki setelah dilaksanakannya sebuah rencana, termasuk legislasi dan program-program, dalam berbagai bidang dan semua tingkat. PUG merupakan strategi untuk membuat masalah dan pengalaman perempuan maupun laki-laki menjadi bagian yang menyatu dengan rencana, pelaksanaan, pengawasan, dan penilaian kebijakan dan program dalam semua aspek politik, ekonomi, dan sosial, supaya perempuan dan lakilaki sama-sama mendapatkan manfaatnya dan ketidaksetaraan tidak akan berlanjut, diaman tujuan akhirnya adalah kesetaraan gender.

\section{METODE PENELITIAN}

Metode penelitian yang digunakan dalam penelitian ini adalah deskriptif dengan pendekatan kualitatif. Adapun teknik pengumpulan data yang digunakan dalam penelitian ini adalah teknik observasi, wawancara dan dokumentasi, dengan teknik analisis data yang digunakan adalah teknik analisis kualitatif. Strategi dalam teknik analisis data deskriptif kualitatif pada dasarnya memiliki sifat yang tidak terlalu mengutamakan makna, sebaliknya penekanannya lebih banyak menganalisi permukaan data, hanya memperhatikan proses-proses kejadian suatu fenomena.

\section{HASIL PEMBAHASAN}

Penelitian ini berjudul Implementasi Program Pengarusutaman Gender Di Provinsi Gorontalo menggunakan jenis penelitian deskriptif pendekatan kualitatif dengan mewawancarai informan yang berhubungan dengan penelitian yang di teliti. Adapun hasil wawancara dari informan yang dilakukan oleh peneliti lebih difokuskan pada perencanaan, pelaksanaan pengawasan dan evaluasi. Peneliti memperoleh data dari informan pemerintah terkait yang mengimplementasikan program pengarusutaman gender antara lain mewawancarai kepala Dinas sosial provinsi gorontalo, beserta kabag dan kasie pemberdayaan dan pengarusutaman gender, serta pegawai sebanyak 6 orang 
untuk mendapatkan informasi terkait dengan implemetasi program pengarusutaman gender.

Adapun hasil penelitian yang peneliti peroleh dari hasil wawancara terkait dengan fokus perencanaan, bahwa perencanaan dalam mengimplempelentaskan program ini sudah dilakukan oleh dinas terkait, dapat dilihat sebelum melaksanakan program sudah disusun draf sebagai pedoman dalam melaksanakan program ini, perencanaan yang dilakukan dengan penguatan kelembagaan PUG agar dalam pelaksanaan ada pedoman yang harus dijadikan patokan, menyediakan sumber daya manusia, anggaran dan sarana prasarana untuk penunjang pelaksanaaan program, serta melaksanakan kerjasama dengan lembaga masyarakat untuk mendukung pelaksanaan program ini dengan melakukan sosilaisasi secara bertahap.

Untuk daerah Provinsi Gorontalo khususnya, tercapainya program-program yang berkaitan erat dengan strategi peningkatan pengarusutamaan gender kemungkinan masih sama dengan kondisi di daerah lain pada umumnya. Dimana, dapat dilihat dari masih rendahnya angka partisipasi perempuan di semua bidang baik politik, pemerintahan, masih kurangnya perhatian dan upaya dalam meningkatkan kualitas hidup perempuan terutama pada masyarakat dengan tingkat ekonomi yang rendah. Dalam kajian adat istiadat yang masih dijunjung tinggi oleh masayarakat Gorontalo dalam setiap pelaksanaan kegiatan, keterlibatan perempuan dalam adat memang sangat kecil.

Dimana, kaum perempuan hanyalah sebagai pelengkap sementara semua peran dalam prosesi-prosesi adat didominasi oleh laki-laki. Dalam kajian masyarakat lokal Gorontalo dengan penguatan kapasitas melalui motto "adat bersendikan sara, sara bersendikan kitabullah" telah menegaskan bahwa peran perempuan dalam lini sosial kemasyarakatan sangat kecil, dan hal inipun telah menjalar pada lini lainnya yaitu politik. Pada intinya, Provinsi Gorontalo masih perlu peningkatan kualitas hidup manusianya, termasuk partisipasi perempuan dalam semua sektor pembangunan.dimana belum adanya upaya pemerintah provinsi gorontalo dalam mensosialisasikan pentingnya gender, serta belum adanya koordinasi dan kerjasama yang sinergi antara pemerintah provinsi dan kabupaten/kota dalam menjalanakna program pengarusutaman gender.

\section{KESIMPULAN}

Pelaksanaan dari program ini sudah dilaksanakan namun sering mengalami kendala disebabkan pelaksana dalam hal ini OPD yang terkait dengan program pengarusutaman gender belum memiliki komitmen untuk melaksanakan program, sering ditemui masih ada beberapa OPD yang tidak mau transparan dalam pelaksanan kegiatan yang berhubungan dengan program ini, OPD memiliki pemahaman bahwa setiap anggaran yang sudah ditetapkan untuk mendukung program pengarusutaman 
gender harus dikelola oleh OPD itu sendiri tanpa harus berkoordinasi dengan bagian yang ditunjuk untuk melaksanakan program.

Sehingga terkesan bahwa koordinasi antara dinas sosial yang membawahi bidang pengarutaman gender dan OPD yang terkait belum maksimal, selanjutnya dilihat dari pengawasan yang dilakukan oleh kepala daerah belum maksimal terkait implementasi pengarusutaman gender ini, dapat dilihat dari sebagian OPD dalam melaksanakaan kegiatan yang berhubungan dengan program pengarustaman gender kurang adanya koordinasi, ini disebabkan pengawasan yang dilakukan oleh kepala daerah terhadap perangkatnya belum maksimal dilakukan, sehingga program ini belum maksimal diterapkan.

Dan dilihat dari evaluasi terhadap implementasi program pengarusutaman gender belum dilakukan, ini dapat dibuktikan dari hasil wawancara peneliti bahwa masih ada OPD yang kurang memahami program yang berkaitan dengan pengarusutaman gender dan masih terdapat juga OPD yang lain tidak melaksanakan kegiatannya dikarenakan anggaran sudah sesuai dengan perencanaan awal sehingga tidak bisa diganggu gugat, sehingga terkesan bahwa evaluasi belum dilaksanakan sesuai dengan ketentuan.untuk itu agar penerapan program pengarusutaman gender dapat dilakukan oleh OPD yang ditunjuk, maka perlu adanya penguatan yang dilakukan oleh dinas terkait dalam hal ini yang melakukan pengawasan agar lebih memberikan pemahaman kepada OPD yang tidak memiliki komitmen, agar supaya dapat mendukung pelaksanaan dari program ini, sehingga program ini dapat dilaksanakan sehingga tujuan awal program pengarusutaman gender dapat terwujud masyarakat dapat meraskan manfaat dari program ini.

\section{DAFTAR PUSTAKA}

Binanto. (2012). Analisis Kebijakan Publik. Yogyakarta: Pustaka Pelajar.

Hartono. (2010). Evaluation Program. Jakarta: Balai Pustaka.

INPRES. (n.d.). Pengarusutamaan Gender Dalam Pembangunan Nasional. Jakarta: Pemerintah Negara Republik Indonesia.

Maggie Hum. (2010). Gender. Bandung: Rineka Cipta.

Sugiyono. (2014). Metode Penelitian Pendidikan Pendekatan Kuantitatif, Kualitatif, dan R\&D. Metode Penelitian Pendidikan Pendekatan Kuantitatif, Kualitatif Dan $R \& D$.

Tahir, A. (2014). Kebijakan Publik \& Transparansi Penyelenggaraan Pemerintah Daerah (1st ed.). Bandung: Alfabeta. 
PUBLIK: Jurnal Manajemen Sumber Daya Manusia, Adminsitrasi dan Pelayanan Publik Sekolah Tinggi Ilmu Administrasi Bina Taruna Gorontalo Volume VIII Nomor 1, 2021

Tangkilisan, H. N. S. (2013). Teori dan Konsep Kebijakan Publik” dalam Kebijakan

Publik yang Membumi, konsep, strategi dan kasus. Lukman Offset Dan YPAPI, Yogyakarta.

Winarno, B. (2014). Kebijakan Publik (Teori, Proses, dan Studi Kasus). Jakarta: CAPS

(Center of Academic Publishing Service).

Yulikospartono. (2013). Pengertian Program. Jakarta: Balai Pustaka. 